\title{
ИНФОРМАЦИОННЫЕ ТЕХНОЛОГИИ В СИСТЕМЕ УПРАВЛЕНИЯ ГОСТИНИЧНЫМ ПРЕДПРИЯТИЕМ
}

Кулинкович М.A. Магистрант Нижегородского государственного педагогического университете имени Козьмы Минина (Нижний Новгород) Крайнова Ольга Сергеевна, канд. экон. наук, дои., зав. кафедрой туризма филиала ЧОУ ВО «Московский университет им. С.Ю.Витте» в г. Нижнем Новгороде

\begin{abstract}
Аннотация: В статье изложены требования к внедрению современных информационных технологий в систему управления гостиничным предприятиям, дано понятие информационного менеджмента, рассмотрено значение информационных технологий для повышения эффективности управления гостиничным предприятием.
\end{abstract}

Ключевые слова: информационные технологии, информационный менеджмент, задачи, решаемые компьютерными системами управления гостиничным предприятием.

Информационные технологии - совокупность методов, производственных и программно-технологических средств, объединенных в технологическую цепочку, обеспечивающую сбор, хранение, обработку, вывод и распространение информации [5, стр. 6]. Информационные технологии предназначены для снижения трудоемкости процессов использования информационных ресурсов.

К современным техническим средствам реализации информационных технологий относятся: персональные компьютеры; локальные и глобальные вычислительные сети; коммуникационные средства; телефонная техника; видеоинформационные системы и др. 
Современные информационные системы предполагают интеграцию различных программных продуктов. В состав информационной системы входят средства для документационного обеспечения управления, информационной поддержки предметных областей, коммуникационное программное обеспечение, средства организации коллективной работы сотрудников и другие вспомогательные технологические продукты. Внедрение информационных технологий предполагает не только автоматизацию основных информационных бизнес-процессов, но и их существенное изменение.

Внедрение современных информационных технологий должно обеспечивать выполнение ряда требований, в том числе наличие удобного и дружественного интерфейса, обеспечение безопасности с помощью различных методов контроля и разграничения доступа к информационным ресурсам, поддержку распределенной обработки информации, использование архитектуры клиент-сервер, модульный принцип построения систем, поддержку технологий Интернет и т.д.

С точки зрения управления сфера туризма представляет собой сложную систему, в которой передаются и обрабатываются большие потоки информации. Качественный уровень управления можно обеспечить только при использовании современных информационных технологий управления.

Сфера информационного менеджмента представляет собой совокупность всех необходимых для управления решений на всех этапах жизненного цикла предприятия, включающая все действия и операции, связанные как с информацией во всех ее формах и состояниях, так и с предприятием в целом [5, С. 47].

Информационные системы менеджмента - это компьютерные системы, включающие в себя программное и аппаратное обеспечение, человеческие ресурсы и обеспечивающие поддержку принятия эффективных управленческих решений [5, С. 60]. Информационные 
системы менеджмента обеспечивают принятие стратегических решений высшим менеджментом, а операционные информационные системы поддерживают обработку данных, необходимых для осуществления текущих бизнес-операций и функциональных операций менеджмента низших уровней.

Компьютерные системы управления гостиничным комплексом позволяют координировать работу гостиничных комплексов и решать задачи: оптимизация бизнес-процессов, снижение бумажного документооборота; повышение контроля над деятельностью служб и персонала; повышение качества обслуживания гостей; оптимизация операционных затрат [3].

На сегодняшний день существует несколько профессиональных разработок, которые заслуживают внимания гостиниц при выборе автоматизированной системы управления. Все системы представляют собой интегрированные пакеты программ, автоматизирующих деятельность основных служб гостиницы: управление номерным фондом, административной, коммерческой, инженерной, службы общественного питания и др. Наиболее известны следующие системы управления гостиницами и отелями: Fidelio, OPERA Enterprise Solution, Epitome PMS, Эдельвейс, «Intellect Style» - «Русский Отель», Отель 2.3, SERVIO HOTEL [6, C. 94].

Точность и быстрота работы профессионально разработанной и отлаженной PMS позволяет значительно снизить время обслуживания и количество ошибок, улучшить качество обслуживания, что влечет за собой минимизацию накладных расходов на лишний персонал, облегчает аудит и способствует росту положительного имиджа средства размещения среди потенциальной клиентуры и партнеров, что, несомненно, наилучшим образом скажется на конкурентоспособности предприятия.

Список источников и литературы: 
1. Вакуленко, Р.Я., Кочкурова Е.А. Управление гостиничным предприятием [Текст]: Учебное пособие для вузов. / Р.Я. Вакуленко, Е.А. Кочкурова. - М.: Тесей, 2010. - 356 с.

2. Демурин В. Б. Современные автоматизированные системы управления гостиницами и их функциональные возможности [Текст] / В. Б. Демурин // Молодой ученый. - 2014. - №8. - С. 162-166

3. Информационные системы управления гостиничными комплексами [Электронный pecypc] // URL: http://www.stroimhotel.ru/files/pdf/ metodology/metod/02.pdf (дата обращения: 25.09.2014)

4. Кобяк М.В., Лайко М.Ю. Технологический прогресс как фактор инноваций в гостиничном бизнесе // Российское предпринимательство. - 2012. - № 18 (240). - с. 126-132. URL: http://www.creativeconomy.ru /articles/29797/ (дата обращения: 12.09.2014)

5. Крайнова, О.С. Логистизация управления предприятиями в сфере информационных технологий [Текст]: диссертация на соискание ученой степени кандидата экономических наук / О.С. Крайнова. Нижний Новгород, 2010.

6. Лебедева Т.Е., Крайнова О.С. Формирование сетевого гостиничного продукта в свете тенденций глобализации [Текст] / Т.Е. Лебедева, О.С. Крайнова. // Индустрия туризма и сервиса: состояние, проблемы, эффективность, инновации. - Сборник трудов: Нижний Новгород, 2014. С. 93-97. 